\title{
A Summary and Commentary on the Quantitative Results of Current NCAA Academic Reforms
}

\author{
Thomas S. Paskus
}

NCAA

\begin{abstract}
The purpose of this paper is to provide an overview of the quantitative analyses informing current academic reforms in the National Collegiate Athletic Association. The article serves as an extension of Petr and McArdle's (2012) previous work. In addition to discussing current reforms in measuring academic success, the author also outlines results from large-scale student-athlete surveys. These data provide a better understanding of current academic reforms and future directions in this area.
\end{abstract}

This paper serves as an extension of what Petr and McArdle (2012) previously presented. First, let me address a couple often-asked questions about the Academic Progress Rate (APR). ${ }^{1}$ APR was a good proxy for eventual graduation success in 2004, and it still is today. I say this based on validation work that we carry out on a continual basis. Teams with the lowest APRs tend to end up with the lowest Graduation Success Rates (GSRs). ${ }^{2}$ Those two rank orderings are not perfectly matched, but they do indicate a high correlation. Over the past decade, tweaks have been made to the APR formula, primarily in how retention points are tallied. But, these changes have not substantially altered that APR to graduation correlation (i.e., how the APR and GSR rank orderings align). The Division I Committee on Academic Performance $(\mathrm{CAP})^{3}$ has not made any changes to the formula without examining the likely statistical impacts. So, I think we feel quite good that the rate itself is fair and about as accurate in predicting graduation as we can get without making it substantially more complicated.

As many know, all 6,400 Division I sport teams are expected to meet a certain standard on a 4-year rolling APR average. That standard will increase from an APR of 900 to one of 930 over the next couple years. The 930 was chosen in large measure because it predicts on average about a $50 \%$ GSR, which is in line with CAP's expectation that teams be on track to graduate at least half their student-athletes. Again, 50\% is an average projection. Because APR and GSR rank orderings are not perfectly matched, as I mentioned, there is variability around those projections. Some teams at 930 will end up graduating more than $50 \%$ and some fewer. That $50 \%$ GSR has been linked with other APRs in the past, including 900 when APR penalties first kicked in a few years ago. This does not mean that the correlation between

Paskus is the Principal Research Scientist, NCAA, Indianapolis, IN. 
APR and graduation has decreased as I have heard some hypothesize - those rank orderings of APR to grad have not changed-all the APRs were just shifted up a bit over time because of the various tweaks to the retention calculation. The APR penalty benchmark has now been shifted upward in part to account for that.

Let us move on to key findings from the APR data. Even after accounting for APR formula changes, APRs have risen across pretty much every sport and subgroup we have examined (See Table 1 and Figure 1). These increases are seen in both

Table 1 Changes in the Average APR, Eligibility Rate and Retention Rate among All Squads Submitting Data in Each Year

\begin{tabular}{lccc}
\hline & Average APR & Average Eligibility & Average Retention \\
\hline $2003-04$ & 961 & 965 & 954 \\
$2004-05$ & 961 & 964 & 954 \\
$2005-06$ & 961 & 964 & 955 \\
$2006-07$ & 964 & 967 & 957 \\
$2007-08^{*}$ & $971^{*}$ & 970 & $968^{*}$ \\
$2008-09$ & 973 & 973 & 969 \\
$2009-10$ & 973 & 974 & 969 \\
\hline
\end{tabular}

Notes:

(1) Analyses based on $N=5,853$ squads that have sponsored the sport within Division I during all seven years of the APR program.

(2) Eligibility and retention rates do not include delayed graduation points (APR does include them).

(3) APR retention calculation changed beginning in 2007-08 to grant point adjustments for certain transfer students. Change did not affect eligibility rate calculation.

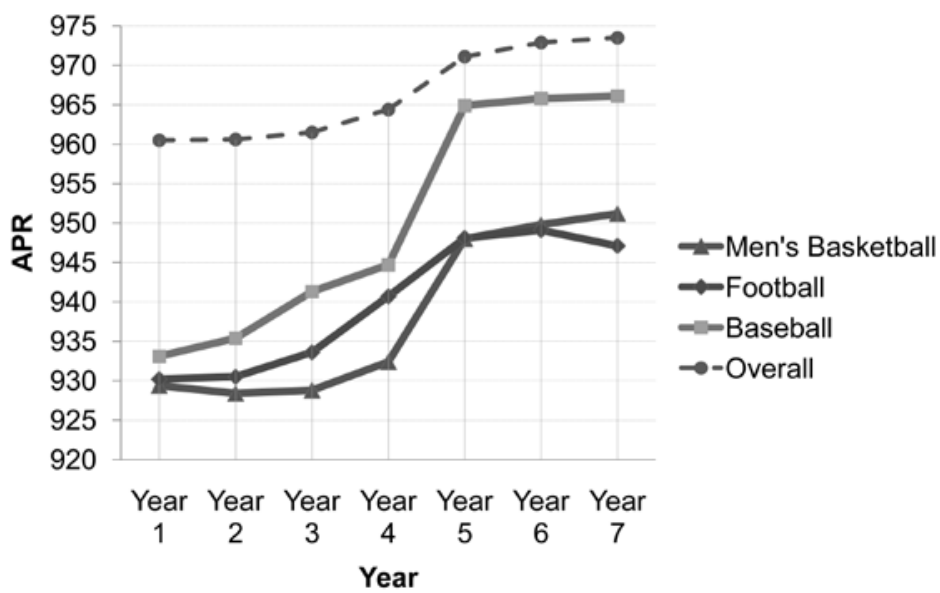

Note: Analyses based on 275 baseball squads, 323 men's basketball squads and 232 football squads that sponsored the sport within Division I during all 7 years. Overall rates include all men's and women's sports, including the three sports displayed. Retention calculation changed in 2007-08 (year 5).

Figure 1 - APR Trends in Baseball, Men's Basketball and Football 
the eligibility and retention components. Sizable decreases have occurred in the number of student-athletes failing out of school and in the number of teams subject to APR penalties. Although it is difficult to statistically argue whether the academic gains were due more to the advent of APR or to the changes in initial eligibility (IE) or progress-toward degree (PTD) rules, ${ }^{4}$ it appears that each has played some role in improving APRs (NCAA, 2011b) and subsequently GSRs (NCAA, 2011c).

APR improvement has not necessarily been steady or universal. Improvement occurred more slowly in some sports due to implementation and education issues. Teams at some colleges improved rapidly - we noted that independent of resources, these schools were quick to recognize deficiencies and make changes to admissions profiles and academic support structures. Other colleges have struggled, including those with less financial resource. A salient concern for CAP is APR trending at Historically Black Colleges and Universities (HBCUs), some of which have not shown improvement and in some cases have actually regressed in their APRs. Various factors have been cited and discussed by CAP including resource, support services, admissions profiles, mission, contest scheduling, high rates of administrative turnover, and early exemption from APR penalties.

We have also learned that academic challenges are more nuanced and sportspecific than we previously realized. Consider the examples of three sports (baseball, football and men's basketball), which stood out as outliers in 2004 with average APRs around 930 (See Figures 1, 2 and 3).

First, let us examine baseball. Behind their low APR, we discovered studentathletes in this sport were arriving in college with grades and test scores roughly half a standard deviation higher than in football and men's basketball. In other words, baseball players were severely underperforming in college relative to what their high school records predicted. Analyses revealed both (a) poor retention rates as participants transferred frequently looking for playing time or small increases

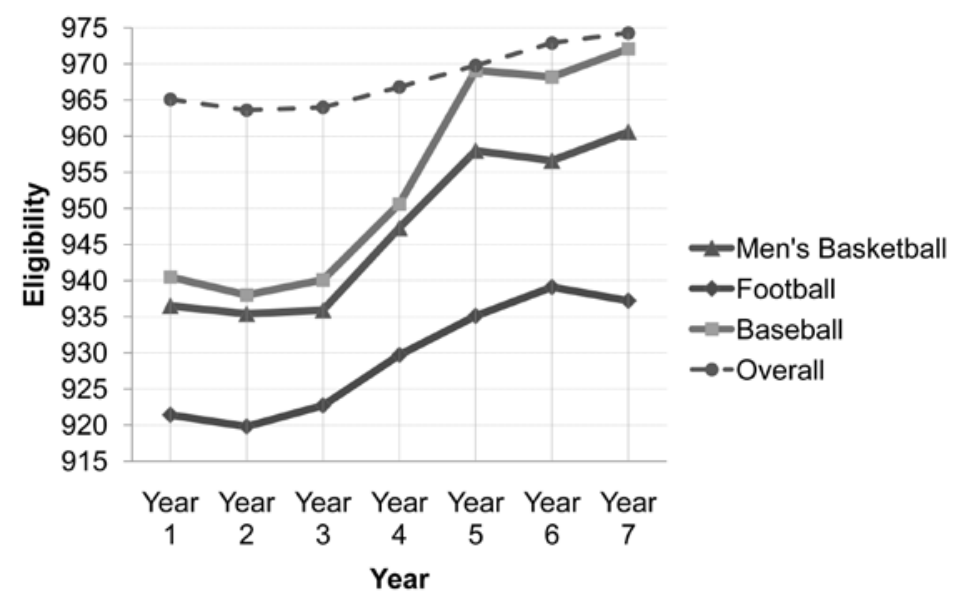

Note: Analyses based on 275 baseball squads, 323 men's basketball squads and 232 football squads that sponsored the sport within Division I during all 7 years. Overall rates include all men's and women's sports, including the three sports displayed.

Figure 2 - Eligibility Trends in Baseball, Men's Basketball and Football 


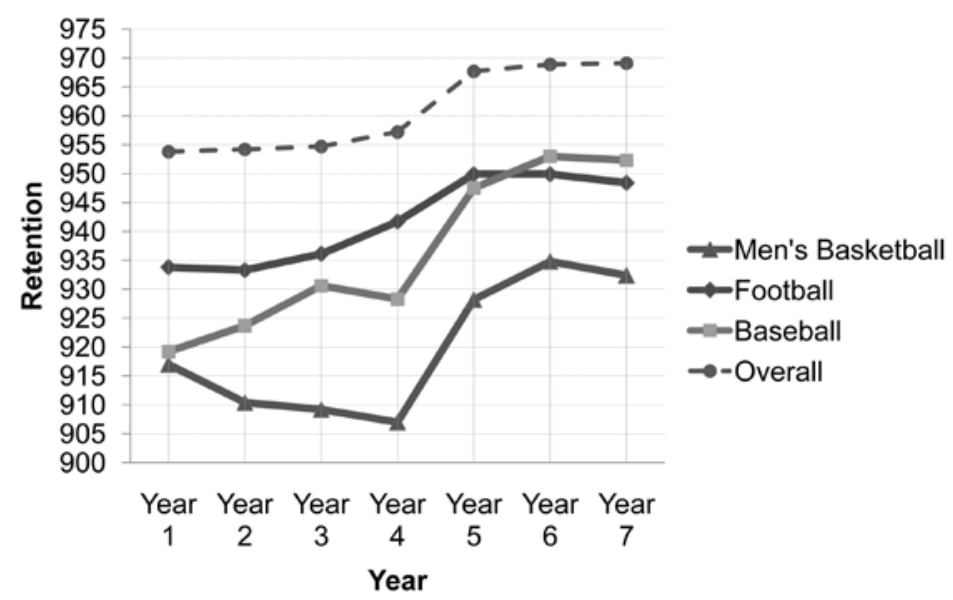

Note: Analyses based on 275 baseball squads, 323 men's basketball squads and 232 football squads that sponsored the sport within Division I during all 7 years. Overall rates include all men's and women's sports, including the three sports displayed. Retention calculation changed in 2007-08 (year 5).

Figure 3 - Retention Trends in Baseball, Men's Basketball and Football

in scholarships; and (b) poor eligibility rates due to a high volume of in-season academic problems. These data led a few years ago to the first modern effort to craft sport-specific PTD rules to deal with problems unique to that sport. ${ }^{5}$ Since those rules took effect, there has been a remarkable APR turnaround in baseball highlighted by an increase in eligibility rates from the 930s to the 970s (Figure 2).

As shown in Figure 2, football continues to have APR issues due primarily to poor eligibility rates. Currently these eligibility rates are about 35 points behind baseball and 25 points behind men's basketball, and not improving at the same rate as in these other sports. Football's issue is primarily related to poor in-season academic performance. New legislation ${ }^{6}$ based on substantial data analysis took effect in the fall of 2011 and will impose more stringent fall-term academic expectations on football players than required for any other sport. Any players not hitting the new benchmark will miss games during the subsequent season.

The average APR in men's basketball is now higher than in football (see Figure 1), but it is still low relative to other sports. Unlike in football, however, the issue is not at all with maintaining academic eligibility. The problem is an extreme retention issue in the sport (see Figure 3). Current data show that fully $40 \%$ of freshman men's basketball players leave their initial school by the end of their second year at that school. These are not so-called one-and-done professional sports departures - few of those actually exist in Division I (10 total in men's basketball during the 2010-11 academic year), and I frankly think focusing on that group is a distraction to the true issue. The vast majority of retention losses are transfers to other schools, typically a search for playing time. The academic issue with such a transfer is that it may have a long-term negative outcome on the student-athlete. Longitudinal research we conducted in our SCORE study (Paskus, Roxbury, Petr, $\&$ McArdle, 2010) indicates that even after we control for academic preparation, 
the act of transferring itself impacts the time to and probability of obtaining an undergraduate degree. This is especially salient among student-athletes who earn low grades at their initial college, which is common in men's basketball. Potential sport-specific remedies to the retention problem are being discussed, but this remains a primary open issue for CAP and the men's basketball community.

As I have highlighted, the new microdata that schools collect as part of calculating APR point us to a couple conclusions that may run counter to previous thoughts. First, the notion that student-athletes tend to perform better academically within the structure of their playing season is incorrect in aggregate (Scott, Paskus, Miranda, Petr \& McArdle, 2008). Consistently in sports where competition occurs exclusively in a single semester, student-athletes are more at risk for veering off the graduation path. This seems to result from the absence of consequences for losing eligibility before an off-season semester and from athletics time demands, which I will discuss shortly. Second, poor APR and graduation is not due to homogeneous factors and not solely a function of academic preparation. There are other factors involved once a student-athlete arrives on campus that may be unique by sport or by school. Academic difficulties are multidimensional and cluster within certain sports or schools in a way that probably should lead to further discussion of tailored approaches to PTD.

Not only do transfers from 4-year colleges perform less well academically than non-transfers in Division I, but transfers from two-year colleges currently perform especially poorly as a group (Paskus et al., 2010). As shown in Table 2, their average APR is 925 or almost 50 points lower than for non-transfers. New data have allowed us to examine for the first time the junior college transcripts of two-year transfers into Division I. We have learned that student-athlete transfers as a group are unlike two-year transfers in the general student body. Only about one- third of two-year transfers in the sports of football and men's basketball met Division I IE standards coming out of high school. Thus, they are often attending the two-year school for academic reasons rather than financial or competitive reasons. Extensive statistical modeling has provided us with three primary takeaways:

1. By far, the best predictor of student-athlete success at the 4-year school is gradepoint average (GPA) at the two-year school. Once we know two-year college GPA, neither high school IE status nor high school GPA / test scores provide any additional predictive information of note. And, to succeed academically at the same rate as a freshman non- transfer, the transfer must exhibit upwards of a 2.60 GPA at the two-year school.

2. GPAs at the two-year school are good predictors of 4-year college success to the extent that they are not based on physical education (PE) activity credits. Generally, I think it was rather surprising and alarming to the various committees to see that more than $20 \%$ of two-year college transfers are currently

\section{Table 2 APR as a Function of Transfer Status (Semester Schools)}

\begin{tabular}{cc}
\hline & 2009-10 APR \\
\hline Non-Transfers & 971 \\
2-Year Transfers & 925 \\
4-Year Transfers & 950 \\
\hline
\end{tabular}


transferring 12 or more PE activity credits into some Division I schools. The new Division I standard will allow only 2 PE activity credits to be counted toward transfer requirements.

3. Two-year transfers who meet a minimum core curriculum at the two-year school of 6 English, 3 math and 3 science credits have ineligibility and failure rates that are half those of transfers who do not take such core academic classes. Keep this research in mind when reading Harrison's (2012) article.

The Division I Board approved one other big academic change in October-new standards for being able to compete in Division I athletics as a first-year college student. Let me show you a graphical representation of the main component of the rule change that takes effect when 2012-13 high school freshmen reach college (Figure 4). I have plotted high school test score on the horizontal access in SAT units and high school core GPA on the vertical axis. The circles represent the number of current Division I freshmen with particular high school academic profiles. As the scale shows, large circles correspond with large numbers of student-athletes. The dotted diagonal line below the shaded strip is the current IE sliding scale; the dotted horizontal line below the shaded band is the current high school core GPA floor for IE of 2.00. You might notice a few small dots below the current standard-about $0.4 \%$ of current Division I freshman fall below the IE scale but become eligible

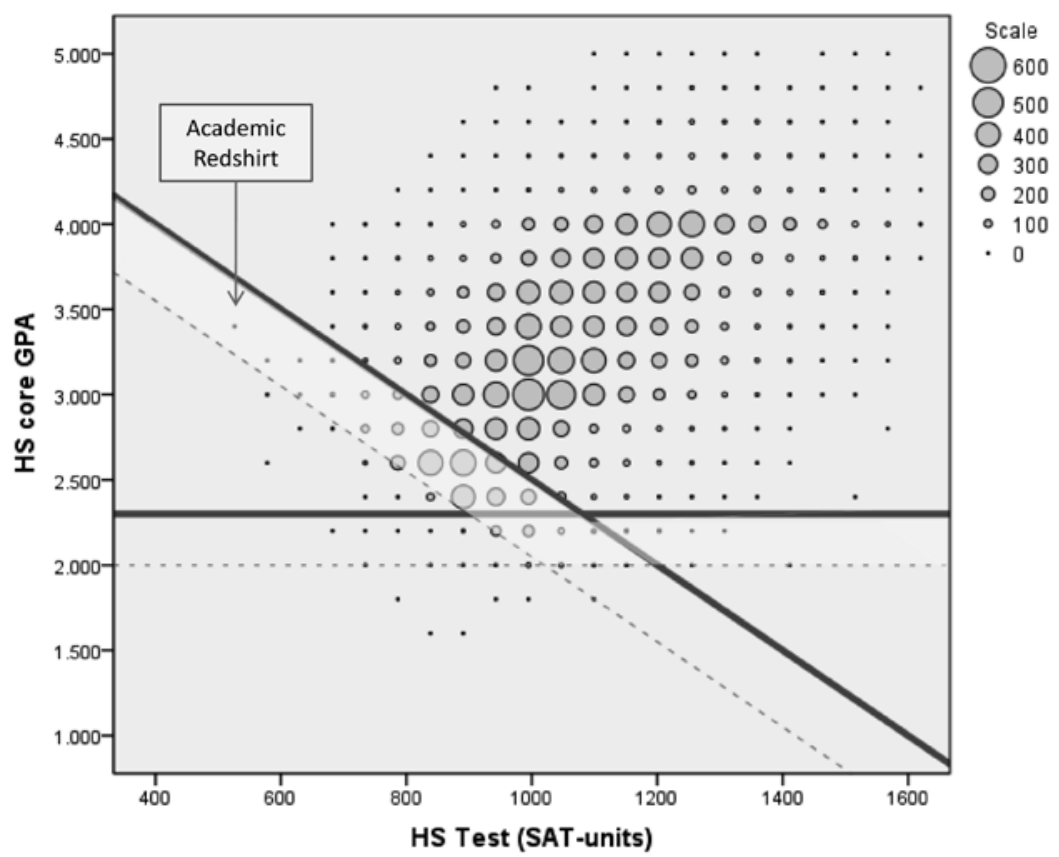

Note: All student-athletes in shaded area would be ineligible for competition only. New sliding scale for competition requires HSCGPA 0.50 units higher for given test score compared to current rule.

Figure 4 - New Division I Initial Eligibility Standards for Fall 2015 (Displayed with Current HS GPA / Test Distribution within Division I) 
through a school's waiver request or enter ineligible as academic nonqualifiers. If we look at the pool of recruited student-athletes, about 3-4\% currently fall below today's standard. Student-athletes not meeting the current Division I IE rules are ineligible for athletics aid, practice and competition.

The new standard that will be in place for freshmen beginning college in 2016 (the dark solid lines corresponding to a higher sliding scale and GPA floor of 2.30) will apply to competition only; all student-athletes above today's standard will still be eligible for athletics aid, will be allowed to practice provided good academic progress is being maintained throughout the year and will get four years of athletics eligibility. But, the competition standard is a game-changer. Any student-athlete whose high school GPA and test score puts them within that shaded band will soon be sitting out of competition for the duration of freshman year. That would amount to about $15 \%$ of current freshman if the rule were in place today. Now, we do not know exactly how the change in standards will impact the academic preparation of prospective student-athletes or recruiting practices of coaches, but within the sports of football and men's basketball, the effects will be substantial. If in effect today, roughly $35 \%$ of freshman football players and $41 \%$ of freshman men's basketball players would be in the midst of an academic redshirt year rather than their first year of competition. So, in essence, what the Board has approved is freshman ineligibility for all student-athletes with sufficiently high academic risk as measured by grades, test score, and core course progression ${ }^{7}$ throughout high school. Student-athletes with stronger academic profiles will be allowed to compete right away, but everyone else will be required to concentrate on academics for a year before competing. Having a year to transition should assist student-athletes who are most at-risk of academic difficulties in college, but I expect outcomes will have a lot to do with how student-athletes and especially institutions use that year. Will schools provide meaningful academic interventions that increase each redshirt's potential for eventual graduation? I think that has to be the case if we expect this change to further increase APRs and GSRs.

As researchers, I think we learned a lot from the discussions leading to the IE changes of 1995 and 2003, which we tried to apply in helping CAP and others make decisions on this occasion. We first modeled college academic outcomes as a function of high school academic variables. We then focused policymaker attention on standards that kept grades and test scores weighted appropriately (roughly 2 to 1 in favor of high school GPA according to our data). This ruled out a host of proposals including those that set a strict cut-off on test scores as was done under the old Proposition 48 and Proposition 16 rules. Surviving models were then presented to the committees with information on potential impacts, efficiency, and fairness. We also provided data on core course progression during high school among both students and student-athletes, which we never had access to previously, allowing for standards to be set that define educationally appropriate high school academic progress. At the end of the day, even with all these data, the committee members were left with a difficult set of decisions. Some came fairly directly from the data (e.g., no hard test cut-off score should be used in Division I) while with others, data served more to illustrate than to direct (e.g., describing the potential numeric impacts of a new standard).

Now to this point, I have talked almost exclusively about the academic predictors of college outcomes. But, the NCAA has also begun to recognize the value of 
speaking to student-athletes themselves about their academic experiences through studies such as GOALS. ${ }^{8}$ What we have learned so far from this research has proven useful in highlighting why we might be seeing various trends in academic performance, why particular issues may be arising in certain sports, and what hurdles we face in improving academic outcomes.

An interesting measure we have studied in GOALS has been student-athlete self-identity. From these data (Table 3), we have learned that student-athletes across all three divisions generally identify very highly as both students and as athletes. That is, identity as a student versus athlete is not at all mutually exclusive. Roughly three-quarters of all student-athletes identify very highly as athletes. Just under two-thirds of men and about three-quarters of women have very high academic identities. Follow-up analyses using the GOALS and $\mathrm{SCORE}^{9}$ data indicate that academic identity in particular is related to various positive academic outcomes including undergraduate and graduate degree attainment. High athletic identity is not itself an indicator of potential academic trouble, but low academic identity is.

The most troubling numbers we have seen historically on the identity measures are not in the sports of men's basketball and football as some might expect, but in baseball. In both Divisions I and II, baseball student-athletes score highest on the athletic identity measure and lowest on the academic identity measure. Given external forces such as the baseball draft (the Major League Baseball draft is comprised of 50 rounds and about 1,500 players are selected, in contrast to a 7-round NFL draft and a 2-round NBA draft), I guess that finding is not surprising. But, it is concerning.

The dreams of a professional career are certainly not limited to baseball, however. The numbers of current student-athletes across division who think it is at least somewhat likely they will become a professional or Olympic athlete in their sport is startling (Table 4). Fully three-quarters of Division I men's basketball players and half of Division II players have such pro expectations. Professional expectations are quite high in baseball, football, and women's basketball as well. And, it is not just limited to Division I or to the so-called revenue sports. Longitudinal modeling shows that these aspirations may slow down degree attainment for all who harbor

Table 3 Self-Identity among Division I Student-Athletes

\begin{tabular}{|c|c|c|c|c|c|c|}
\hline \multicolumn{7}{|c|}{ Percentage of Student-Athletes with High Athletic Self-Identity } \\
\hline Baseball & $\begin{array}{c}\text { Men's } \\
\text { Basketball }\end{array}$ & $\begin{array}{l}\text { Fo } \\
\text { (FB }\end{array}$ & $\begin{array}{l}\text { oall } \\
\text { FCS) }\end{array}$ & $\begin{array}{l}\text { All Other } \\
\text { Men's } \\
\text { Sports }\end{array}$ & $\begin{array}{l}\text { Women's } \\
\text { Basketball }\end{array}$ & $\begin{array}{c}\text { All Other } \\
\text { Women's } \\
\text { Sports }\end{array}$ \\
\hline $87 \%$ & $80 \%$ & $79 \%$ & $78 \%$ & $79 \%$ & $65 \%$ & $78 \%$ \\
\hline
\end{tabular}

\begin{tabular}{|c|c|c|c|c|c|c|}
\hline \multicolumn{7}{|c|}{ Percentage of Student-Athletes with High Academic Self-Identity } \\
\hline Baseball & $\begin{array}{c}\text { Men's } \\
\text { Basketball }\end{array}$ & $\begin{array}{l}\text { Fo } \\
\text { (FBS }\end{array}$ & $\begin{array}{l}\text { all } \\
\text { CS) }\end{array}$ & $\begin{array}{l}\text { All Other } \\
\text { Men's } \\
\text { Sports }\end{array}$ & $\begin{array}{l}\text { Women's } \\
\text { Basketball }\end{array}$ & $\begin{array}{c}\text { All Other } \\
\text { Women's } \\
\text { Sports }\end{array}$ \\
\hline $51 \%$ & $60 \%$ & $61 \%$ & $64 \%$ & $62 \%$ & $64 \%$ & $77 \%$ \\
\hline
\end{tabular}

Note: $\%$ indicating an average score of 5 or higher on a 6-point scale. 
Table 4 How likely do you think it is that you will become a professional and/or Olympic athlete in your sport? (\% responding at least 'somewhat likely')

\begin{tabular}{|c|c|c|c|c|c|c|}
\hline \multicolumn{7}{|c|}{ Division I } \\
\hline \multirow{2}{*}{$\frac{\text { Baseball }}{60 \%}$} & \multirow{2}{*}{$\begin{array}{c}\begin{array}{c}\text { Men's } \\
\text { Basketball }\end{array} \\
76 \%\end{array}$} & \multicolumn{2}{|c|}{$\begin{array}{c}\text { Football } \\
\text { (FBS, FCS) }\end{array}$} & \multirow{2}{*}{$\begin{array}{c}\text { All Other } \\
\text { Men's } \\
\text { Sports } \\
37 \%\end{array}$} & \multirow{2}{*}{$\begin{array}{c}\begin{array}{c}\text { Women's } \\
\text { Basketball }\end{array} \\
44 \%\end{array}$} & \multirow{2}{*}{$\begin{array}{c}\text { All Other } \\
\text { Women's } \\
\text { Sports }\end{array}$} \\
\hline & & $58 \%$ & $46 \%$ & & & \\
\hline \multicolumn{7}{|c|}{ Division II } \\
\hline $43 \%$ & $48 \%$ & & $\%$ & $30 \%$ & $25 \%$ & $10 \%$ \\
\hline \multicolumn{7}{|c|}{ Division III } \\
\hline $19 \%$ & $21 \%$ & & $\%$ & $13 \%$ & $5 \%$ & $5 \%$ \\
\hline
\end{tabular}

them, and perhaps worse for those with low academic identity and low levels of academic engagement. Consensus is that these numbers are a primary fuel for the retention issues in men's basketball.

We also see in GOALS that athletics reasons affect choice of college across all three divisions. More than $80 \%$ of student-athletes report that athletics participation contributed to their specific school choice, which is substantially higher than the reported contribution of academic factors. That does not necessarily mean they do not see academics as important; more than $90 \%$ of Division I studentathletes across sport say graduation from college is important to them. Rather, it appears they choose between colleges they perceive as academically similar based on expected playing time or connection to a coach. Intriguingly, student-athletes report a greater mismatch between athletics expectations coming into college and actual experiences than they do between academic expectations and experiences. Across all three divisions but especially in Divisions I and II, the data are clear that the presence of a particular coach has a strong impact on student-athlete college choice, no more so than in men's and women's basketball. Now, before you single out basketball coaches for some form of deception in advertising, consider that of all sports studied, Division I men's basketball coaches were seen by their players as having the most personal interest in whether they earn a college degree or not. Given the retention issues in the sport, I think the current discussions in the membership about enhancing the ability of basketball coaches to spend more time with recruits and current student-athletes align logically with the data.

In GOALS, we also asked student-athletes specifically about their academic experiences in college. These data are interesting, but difficult to judge without comparison with nonathletes at the same schools. For example, I am fairly certain that college students are not unanimous in liking all their coursework or their majors. But, we can assert a few things. Roughly $80-85 \%$ of Division I studentathletes report that they would likely have taken the same classes they did even if they were not student-athletes, with somewhat lower numbers observed in Football Bowl Subdivision (FBS) football. However, nearly half of Division I studentathletes across sport admitted that practice schedules played a role in their course choices, and a quarter of student-athletes in the sports of football, baseball, and 
women's and men's basketball agreed that eligibility concerns played a role in course choice. Regrets about the impact of athletics participation on course choice or major (Table 5) are quite low but not similarly low in all sports (e.g., 12\% of FBS football players reported regrets about their majors). There is more research to be done on this topic, but some of it needs to occur on your campuses. Take the issue of major clustering. It is difficult to conduct a proper statistical analysis at a national level given the data we currently have because (a) we do not have good information on how nonathletes distribute in specific majors at each college, (b) we do not have any basis for rating the quality of a major on a given campus and (c) when compiled nationally, specific majors tend to be shoehorned into categories that mask clustering. We will continue to pursue research on this topic, but I would be happy to share my methodology ideas with anybody looking to perform these analyses well at their schools.

In my opinion, some of the most valuable data coming out of the GOALS study have been on time commitments. Across sport and division, student-athletes are devoting a great deal of time to both their schoolwork and their sport. On the athletics side, self-reported in-season time commitments range from just under 30 hours/week to about 43 hours/week (Table 6). Note that the highest athletics time commitments in Division I occur in football and baseball- the two sports that have historically had APR eligibility rate problems. Self-reported time on academics is similar in magnitude, with the lowest numbers seen in Division I and II baseball (note that baseball also shows the worst academic to athletic time differential during their competition season). This means that in total, the typical student-athlete spends more than 70 hours/week on these two endeavors alone, with the highest totals in Division I football (about 81 hours/week) and Division I basketball (both men and women at about 77 hours/week). I think it is also clear from the data that across sport and division, athletics is a year-round activity. When we asked GOALS participants the open-ended question, "If you could change one thing about your

\section{Table 5 Division I Student-Athlete Self-Report of Issues with Major Choice (among those who have selected a major)}

\begin{tabular}{|c|c|c|c|c|c|c|}
\hline \multicolumn{7}{|c|}{ If you weren't a college athlete, would you still choose your current major? } \\
\hline & Baseball & $\begin{array}{c}\text { Men's } \\
\text { Basketball }\end{array}$ & $\begin{array}{c}\text { Football } \\
\text { (FBS, FCS) }\end{array}$ & $\begin{array}{l}\text { All Other } \\
\text { Men's } \\
\text { Sports }\end{array}$ & $\begin{array}{l}\text { Women's } \\
\text { Basketball }\end{array}$ & $\begin{array}{c}\text { All Other } \\
\text { Women's } \\
\text { Sports }\end{array}$ \\
\hline $\begin{array}{l}\text { Probably/ } \\
\text { Definitely } \\
\text { Not }\end{array}$ & $16 \%$ & $15 \%$ & $10 \%$ & $7 \%$ & $9 \%$ & $7 \%$ \\
\hline
\end{tabular}

\begin{tabular}{lcccccc}
\hline Has athletics participation prevented you from majoring in what you really want? \\
\hline & $\begin{array}{c}\text { Men's } \\
\text { Baseball }\end{array}$ & $\begin{array}{c}\text { Football } \\
\text { Basketball }\end{array}$ & $\begin{array}{c}\text { All Other } \\
\text { Men's } \\
\text { (FBS, FCS) }\end{array}$ & $\begin{array}{c}\text { Women's } \\
\text { Sports }\end{array}$ & $\begin{array}{c}\text { All Other } \\
\text { Women's } \\
\text { Basketball }\end{array}$ & \begin{tabular}{c} 
Sports \\
\hline $\begin{array}{l}\text { Yes and I } \\
\text { regret it }\end{array}$
\end{tabular} \\
\hline
\end{tabular}




\section{Table 6 Average Hours Spent Per Week In-Season on Athletic Activities in 2010 (SA Self-Report)}

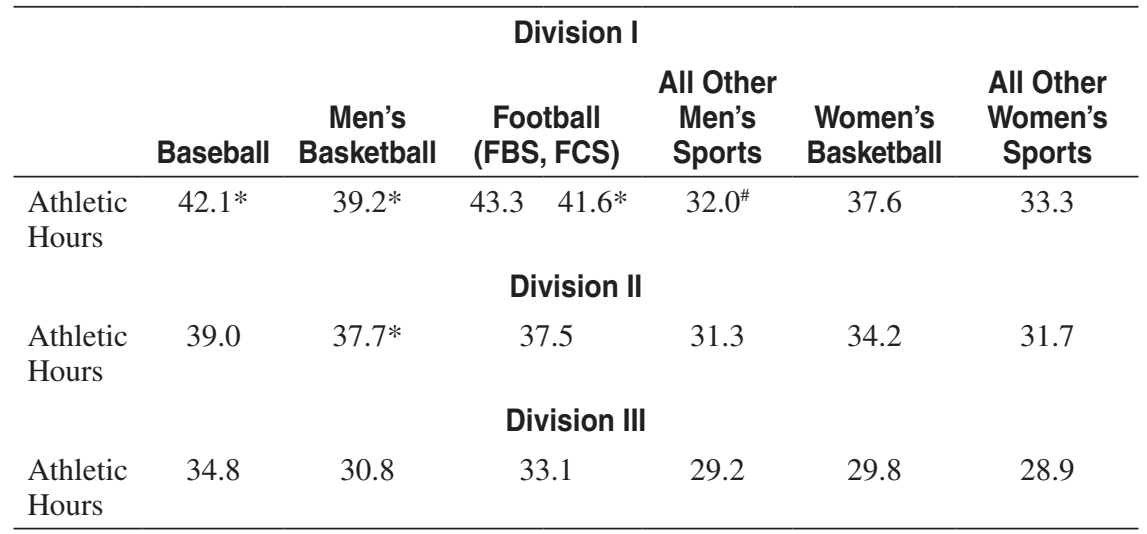

Note: *Increase of $2+$ hours on athletics from 2006; ${ }^{\#}$ Decrease of $2+$ hours on athletics from 2006

student-athlete experience, what would it be?", the most frequent response by far was something related to time demands $(31 \%$ of respondents cited time issues in FBS football and over 30\% cited in a number of women's sports). Other categories of desired changes that you might think would be salient to student-athletes (for example, major, classes, facilities, finances) were not even close-they were generally endorsed in the low single digits within Division I sport groups.

\section{Summary and Conclusions}

While there is far more I could cover, in the interest of parsimony, I will close with several broad summary points. First, we have made some progress, but need to make more in how we conceptualize academic risk among student-athletes. At the individual level, it is clear that risk is nuanced and complex. New data are allowing us to see that academic risk is a continuous and dynamic entity, and there are structures or cultures in certain sports that may enhance risk. Some factors contributing to academic risk among student-athletes are shared with their peers in the student body, but others are unique factors, such as identity, professional sports aspirations, satisfaction with their place on the team, connection with a coach, time demands, and academic support structures. Demographic risk factors (such as distance from home or first-generation status) may be differentially salient among student-athletes, and other factors, like attitude toward major, may be more complexly related to academic completion than among other students. And, these factors, and the corresponding academic risk level, can change very quickly for a student-athlete. Schools should develop ways to assess and assist student-athletes in real-time as issues arise potentially impacting academic satisfaction and success in obtaining a degree (see the NCAA FLAG program for an example of multivariable dynamic risk assessment; Paskus, 2009).

Second, at a team or school level, there is substantial variation in recognition, ability, and willingness to manage academic risk in the aggregate. The teams having 
APR or GSR troubles do not get to that point because their school admitted a few student-athletes who were near the NCAA minimums. They are consistently teams admitting high numbers (or even exclusively) student-athletes who clearly predict to have trouble with college work given their high school or two-year college academic record. Even highly resourced academic support programs will struggle to serve their student-athletes if every member of a team has substantial academic risk. Colleges must recognize the magnitude of aggregate risk they are taking on and make appropriate adjustments. They can do so, for example, by enhancing academic support systems, by developing better models for understanding studentathlete academic risk at the individual level, or perhaps by capping the number of high-risk student-athletes admitted at any given time. The latest enhancements to Division I academic standards (e.g., elevated APR standard for postseason competition) will have substantial consequences for colleges that do not actively attend to and manage their composite risk levels.

I leave it to you to decide whether academic reform has been successful. I do think it is clear, however, that the NCAA's decisions about academic standards have never been more data- based. Walt Harrison, CAP, and a number of others in the NCAA community who have been involved in the reform efforts deserve a lot of credit for this. I do suggest that this has resulted in our being able to make changes and implement policy based on empirical analyses and data-factors that result in improved decision making.

\section{Notes}

1. The Academic Progress Rate is a real-time term-by-term accounting of academic data from individuals on the squad. Teams with historic underperformance on APR are subject to various penalties designed to improve academic outcomes. See Petr and Paskus (2009) for a more detailed description of APR calculations.

2. The NCAA's Graduation Success Rate is calculated much like the standard federal graduation rate, but it takes into account transfer movement into and out of schools. See Petr and Paskus (2009) for detail on how GSR is calculated.

3. The NCAA's Division I Committee on Academic Performance, currently chaired by President Walter Harrison of the University of Hartford, oversees the NCAA's Academic Performance Program, APR and other academic regulations.

4. Division I IE and PTD standards were revised beginning for the class entering college in the fall of 2003 (same time that APR came on-line). The IE revisions included removal of a hard test cut-score in favor of a full sliding scale of high school GPA and test scores, as well as an increase in the number of core academic courses required in high school. The PTD standards were strengthened to necessitate student-athletes maintaining no slower than a five-year course toward graduation to stay eligible for competition.

5. See NCAA Division I bylaw 14.4.3 for more information on the baseball-specific rules (NCAA, 2011a).

6. See NCAA Division I bylaw 14.4.3.1.6 for more information on the football-specific rules that took effect in 2011 (NCAA, 2011a).

7. The core course progression will require that student-athletes meet 10 of the 16 required high school core courses (and 7 of the 10 required in English, math and science) by the start of the senior year in high school. Failure to meet the progression standard will trigger the academic redshirt year even if the student-athlete meets the other academic standards by end of senior year. 
The reasoning behind this legislation was to promote educationally appropriate course progression during high school.

8. GOALS (Growth, Opportunities, Aspirations and Learning of Students in college) is an NCAA study conducted in 2006 and 2010 across all three divisions. 20,000 student-athletes in both versions answered questions about their athletics, academic and social experiences in college. See www.ncaa.org for more information on the study and associated findings.

9. SCORE (Study of College Outcomes and Recent Experiences) is an NCAA study of former college student-athletes (surveyed at approximately age 30). See www.ncaa.org for more information on the study and associated findings.

\section{Acknowledgments}

I would like to thank Todd Petr, Jack McArdle and all of the members of the NCAA research team for their contributions to the work referenced in this paper. Thank you to all of the current and former student-athletes who have participated in NCAA studies, as well as to the faculty and administrators involved in data collection. This work has benefitted greatly over the years from the comments and suggestions of many members of the NCAA staff, NCAA committees and the college athletics community.

\section{References}

Harrison, W. (2012). NCAA academic performance program (APP): Future directions. Journal of Intercollegiate Sport, 5, 65-82.

National Collegiate Athletic Association. (2011a). 2011-12 NCAA Division I Manual. Indianapolis, IN: National Collegiate Athletic Association.

National Collegiate Athletic Association. (2011b). National and sport-group APR averages, trends and penalties (NCAA public release on APR). Retrieved from http://www.ncaa. org/wps/wcm/connect/4bd0070046f99f8dbd72fdc110a6426c/APR.pdf? MOD=AJPE RES\&CACHEID=4bd0070046f99f8dbd72fdc110a6426c

National Collegiate Athletic Association. (2011c). Trends in graduation-success rates and federal graduation rates at NCAA Division I institutions (NCAA public release on graduation rates). Retrieved from http://www.ncaa.org/wps/wcm/ connect/e9eb8a0048d2623fb424ffb1fe52de76/GSR+and+Fed+ Trends+2011++Final+10_20_11.pdf?MOD=AJPERES\&CACHEID=e9eb8a0048d2623fb424ffb $1 \mathrm{f}$ e52de76

Paskus, T.S. (2009, May). Improving predictions of academic outcomes for college studentathletes. Paper presented at the annual meeting of the Association for Psychological Science, San Francisco, CA.

Paskus, T.S., Roxbury, T.L., Petr, T.A., \& McArdle, J.J. (2010, April). The effects of transferring on college student-athletes. Paper presented at the annual meeting of the American Educational Research Association, Denver, CO.

Petr, T.A., \& McArdle, J.J. (2012). Academic research and reform: A history of the empirical basis for NCAA academic policy. Journal of Intercollegiate Sport, 5, 27-41.

Petr, T.A., \& Paskus, T.S. (2009). The collection and use of academic outcomes data by the NCAA. New Directions for Institutional Research, 144, 77-92 10.1002/ir.315. doi:10.1002/ir.315

Scott, B.M., Paskus, T.S., Miranda, M., Petr, T.A., \& McArdle, J.J. (2008). In-season vs. out-of- season academic performance of college student-athletes. Journal of Intercollegiate Sport, 1, 202-226. 